\title{
Drill Method to Improve Diabetic Ulcer \\ Treatment Competency
}

\author{
Diah Merdekawati* \& Ani Astuti \\ Program Studi Ilmu Keperawatan \\ STIKes Harapan Ibu Jambi \\ Email* : zelvyeliva@gmail.com
}

\begin{abstract}
Introduction: Adolescents who get social media addiction, dopamine discharges occur in their bodies that create anxious feelings that can cause problems in social behavior in schools, living quarters, and peer social environments, and even trigger criminal acts such as defamation, slander, kidnapping, and fraud. The purpose of this research was to analyze the relationship between social media addiction and anxiety and the risk of social health disasters in adolescents. Methods: This research method is quantitative analytic descriptive with a cross-sectional design. The number of research samples was 79 students from the total population of 385 one of the junior high school students in the Yogyakarta region of Indonesia. Data retrieval technique in this research uses Stratified Random Sampling technique. Data on social media addiction, anxiety and the risk of social health disaster were collected using questionnaires and analyzed by Spearman Rank Test, a numerical correlation statistical test, with SPSS 21. Results: The results showed that the mean value of the age variable was 13.91, social media addiction was 60.38, anxiety was 14.46, and the risk of social health disaster was 67.97. The results of the statistical hypothesis test obtained that there was no significant relationship between social media addiction, anxiety, and social health disaster risk variables in adolescents. Conclusions: The conclusion of this research obtained that social media access can cause negative and positive impacts. Anxiety and the risk of social health disasters events are thought to be influenced by external factors.
\end{abstract}

Keywords: Adolescents; Addiction; Social Media; Anxiety; Social Disaster.

\section{INTRODUCTION}

Diabetes mellitus (DM) is a common degenerative disease that increasingly every year in around the world. According to International of Diabetic Frederation, the prevalence of diabetes mellitusin worldwide is 366 million in 2010and increasing at 387 million in 2014 (IDF, 2015). Indonesia in $7^{\text {th }}$ country with diabetes mellitus at 8,5 million after China, United States, Brazil, Russia and Mexico

Patients with diabetes mellitus are at risk for developing complication due to unstable blood sugar level. One of complication of diabetes mellitus is diabetic ulcer. According to PD Persi (2013), in Indonesia the cases of diabetic ulcer and diabetic gangrene are the most cases which treated in the hospital. The number of deaths caused by diabetes mellitus ranges from $17 \%-23 \%$ and amputation rates from $15 \%$ dan $30 \%$.
Primary Health Center (PHC) Simpang IV Sipin as a PPHC with highest number of diabetic mellitus patients as many 1667 people than other PPHC in Jambi City. Based on interviews with nurses inPrimary Health Center (PHC)Simpang IV Sipin Jambi City, they still use conventional wound care by using normal saline solution.

The research conducted by Edi et al (2013) shows the importance to applying modern wound care management, especially applied in the hospital. The study applied by Diah\&Rasyidah (2017) says there is a relationship between principle and dressing with moist wound healing techniques. Other study conducted by Suyanto\&Ahmad (2017) says that modern wound irrigation devices can reducing the number of bacteria in patients with diabetic ulcer

There is necessary for the nurses to change the wound care method from conventional wound care become modern wound care. Beside that, the nurses must have an adequate 
knowledge and skills related to the wound care process, starting from comprehensive assessment, planning for the intervention, implementing the action, evaluating the results during the treatment and systematic documentation (Agustina, 2009). Therefore, there is need for renewal of knowledge.

One of the learning method that can be implemented to improve the competence is drill method. The research conducted by Sudira et al (2013) explains the difference in learning achievement after using the drill method. The results in line with study by Rika (2017) shows that the drill method can increase understanding of mathematical concepts. The study finding similar to other study conducted by Haswita \& Lina (2014) says that drill method can improve learning achievement. This study aimed to determine the effect of drill method in competence of treating diabetic ulcer.

\section{METHODS}

Pre-experimental study by using one group pre-post test design was appied in this study. This study conducted by doing pre-test (early observation) before giving intervention, then post-test (the last observation) was carried out again.

There were 36 participants recruited from Primary Health Center (PHC) in Simpang IV Sipin Jambi City between 16 July - 16 August 2018. Total sampling method was used for sample selection. The sample in this study were all nurses in Primary Health Center (PHC) in Simpang IV Sipin Jambi City who willing participate in this study.

The instrument in this study by using selfadministered questionnaire and observation sheet to assess competence of nurses in cognitive, affective, and psychomotor aspects before and after giving drill method as learning method.To assess cognitive aspect, the researcher using self-administered questionnaire. While for assess affective and psychomotor aspects, the researcher using standard operasional procedure for modern dressing.

This study has been approved by Ethics Review Boards (ERB) Committee in Medical Faculty of Jambi University with the approval number 899/UN21.6/LT/2018 on July 2018.

Descriptive statistic was used to determine the characteristic of participants. Educational level was calculated by using percentage and frequency. Bivariate analysis by using Wilcoxon test.

\section{RESULTS}

All of the participants start the research object by doing pre-test before giving drill method as learning method to determine competence of nurses in treating modern wound care. Characteristic of participants based on educational level were analyzed.

Table 1. Distribution of number and percentage of educational level of the participants

\begin{tabular}{lcc}
\hline \multicolumn{1}{c}{ Variable } & N & \% \\
\hline Educational level & & \\
\hline & & \\
Advance education (nursing school) & 20 & 55,6 \\
Diploma & 10 & 27,8 \\
Bachelor & 6 & 16,6 \\
& & \\
\hline
\end{tabular}

More than half of the participants $(55,6 \%)$ had finished their nursing school as advance education (See Table 1). The result of competence of nurses in cognitive, affective, and psychomotor aspects before giving drill method were analyzed. 
Table 2 Distribution of number and frequency competence of participants before giving drill method

\begin{tabular}{lcc}
\hline Variable & N & \% \\
\hline Cognitive & 11 & 30,6 \\
Low & 15 & 41,6 \\
Fair & 10 & 27,8 \\
High & 36 & 100 \\
\hline Affective & 0 & 0 \\
Low & & 0 \\
High & 0 & 100 \\
\hline Psychomotor & 36 & \\
Low & & \\
\hline
\end{tabular}

More than one third of the participants $(41,6 \%)$ were at the fair in cognitive aspect, all of the participants $(100 \%)$ were at the low in affective aspect, and all of the participants $(100 \%)$ were at hign in psychomotor aspect
(See Table 2). The result of competence of nurses in cognitive, affective, and psychomotor aspects after giving drill method were analyzed.

Table 3 Distribution of number and frequency competence of participants after giving drill

\begin{tabular}{lcc}
\hline Variable & N & \% \\
\hline Cognitive & 1 & 2,8 \\
Low & 10 & 27,8 \\
Fair & 25 & 69,4 \\
High & 0 & 0 \\
\hline Affective & 36 & 100 \\
Low & 0 & 0 \\
High & 0 & 100 \\
\hline Psychomotor & 36 & \\
\hline High & &
\end{tabular}

The majority of the participants $(69,4 \%)$ were at high in cognitive aspect, all of the participants $(100 \%)$ were at high in affective aspect, and all of the participants $(100 \%)$ were at high in psychomotor aspect. Cognitive and affective aspects showed increase after giving drill method (See Table $3)$.

Bivariate analyse by using Wilcoxon test to determine the differenciate competence of participants before and after giving drill method were analyze. 
Tabel 4 The differenciate competency of participants before and after giving drill method

\begin{tabular}{cccc}
\hline Variable & N & Median & P-value \\
\hline Cognitive in before & 36 & 6 & 0,000 \\
Cognitive in after & 36 & 8 & \\
\hline Affective in before & 36 & 2 & 0,000 \\
Affective in after & 36 & 7 & 0,000 \\
\hline Psychomotor in before & 36 & 19 & \\
Psychomotor in after & 36 & 22 &
\end{tabular}

The result as shown in Table 4 showed there was the significantly difference between competency of participants in giving diabetic ulcer in terms of cognitive, affective, and psychomotor aspects. The competency of participants showed increasing after giving drill method $(p$-value $=0,000)$.

The difference in ulcer skale in diabetic ulcer patients before and after treating drill method were analyzed.

Tabel 5 The difference in ulcer scale before and after drill method

\begin{tabular}{cccc}
\hline Variable & N & Median & P-value \\
\hline Ulcer in before & 36 & 15 & 0,000 \\
Ulcer in after & 36 & 8 & \\
\hline
\end{tabular}

The result as shown in the Table 5 showed there was differenceulcer scale before and after treating drill method.

\section{DISCUSSION}

This study found that the competence of participants before giving drill method showed that, the most of them were at the low-fair in cognitive aspect, low in effective aspect, and high in psychomotor aspect.

The findings are in line with the privious study showed that ability of students before giving drill method as learning method was still low. The students had difficulties to understanding and applying the ability to write in English (Swanto, 2014). This study are similar to the research conducted by Sulistyowati (2013) showed that ability of students about accounting was not optimal, due to the average score of student was still below the passing grade.

Learning method had important role to achieve the success in improving competence of nurse to provide nursing services for the patients. The previous study showed that the quality of providing nursing services was
There was decrease in ulcer scale in diabetic ulcer patients..

directly related to the learning method and directly application for the patients maximally (Hinno et al, 2012).

This study finding also showed that psychomotor competence of nurse in treating wound care had a good result, due to the majority of nurses had a good experience and also exposed to treating conventional wound care. The experience was important and could not separate from one's competence in providing of nursing services. According to Nieminen in Mannavaara \& Fagerstrom (2011) said that experience also had important role in ability of nurses in providing of nursing services. The nurses often exposed to certain cases were make them more willing to take the action.

After giving drill method, competence of nurses in treating modern wound care showed improvement in terms of cognitive, affective, and psychomotor aspects.

This research are align with the research conducted byFransiska\&Jurianto 
(2016) showed that after giving drill method, the average score of students were significantly increase. Supported by other research conducted by Khetgury \& Albay (2016) showed that increase ability to speak in English for students after giving drill method.

Drill method as learning method is one of technique that can be used to increase ability in cognitive, affective, and psychomotor aspects. According to Hamdani (2011) said that drill method could improve ability of students to perform skill permanently. The similar research was conducted by Sagala (2013) said that drill method as the way to get agility, opportunity, and skill. In this research, the researcher was used discussion, demonstration, and simulation as a technique. On the discussion forum, speaker who expert in wound care was invited to give learning material and. Then, demonstration was carried out by bringing patient with grade 2-3 diabetic ulcer acccording to Wagner scale. The demonstration were carried out by modern wound care expert, then participants were given the opportunity to simulate how to treating patient directly.

Simulation or direct practice to the patients could provide the experience which make participants were given the opportunity to explore the knowledge that they had and without afraid or failure with the action that they taken. The problems that were found could be identified and found solution directly. According to Walton, Chute and Ball (2011) used simulation method could make students able to learn without afraid or failure and also could identify problems directly for the problem of knowledge that they found. Simulation could make students to transfer the skill and knowledge that they have inclinical practice which make them more confident.

More than few decades, direct simulation method to the patients as a method that had been used in nursing education and proven effective in learning strategy (Lee et al, 2003). Directly simulation to the patients were more effective to improve ability in terms of cognitive, affective, and psychomotor for learning strategies in nursing education (Jeffries andNirton, 2005). In addition, Whitemen
andBackes, (2014) said that the significant strategy to improve knowledge and satisfaction in learning outcome of student by directly simulation to the patients.

The results of bivariate analysis showed that the difference competence of nurses before and after giving drill method in terms of cognitive, affective, and psychomotor aspects ( $\mathrm{p}$-value $=0,000$ ). This study finding found that statistically difference in competence of nurses in modern wound care. There were $100 \%$ of nuses' knowledges and attitudes become increase.

This study finding are in line with the study conducted by Zapko et all (2015) by using drill method showed that difference competency of nursing students in interdisciplinary disaster nursing. The results showed that the nursing students were more convident to provide clinical practice, due to they had experience in directly simulation to the patients. Supported by other research by Kani (2015) explained that drill method was effective learning method for improved learning skill.

Drill method as learning concept that aimed to improve ability in side of knowledge and skill, this method was effective to used in learning process in multi disciplines. According to Usman (2002) performed drill method as learning method that was aimed to get skill from learning process, because by using directly demonstration could improve the knowledge. In addition, the research conducted by Muslih (2009) explained that drill method as learning method whose students were given direct training to understand the material which provided.

The alternative learning method were used to improve ability of nursing by using drill method which explore ability of nursing with training skill and achievement model. The previous study conducted by Wenno et al (2016) which compared between conventional method and drill method. The result showed that drill method was better than conventional method. Delazer et al (2009) stated that practicing active skills could increase the ability to understand the material provided, creating spontaneous learning, and bring the students to get new situation. Brekke andHogstad (2010) stated that drill method model approach was apply 
from theory to practice and the feedback achieved to increase ability of students.

In terms of the difference in wound scale, this study finding showed there were differences in wound scale before and after treating modern wound care by using drill method as learning method ( $\mathrm{p}$-value $=0,000$ ). The average of decreasing in wound scale after treating wound care by using modern wound care were showed decrease in wound scale, significantly wound healing, covering the wound area, depth and volume of exudates.

The application of drill method as learning method in this study were each nurses devided into several groups, each group treated wound care during in 12 days with 6 times of visiting to the patients who had diabetic ulcer in wound grade 2-3 based on Wagner scale. From the result of the observation showed that were 6 times of visiting to the patients had improve in knowledge and understanding about application in wound care by using modern wound care. Direct practice to the patients, the nurse had experience in line with the knowledge. There were made wound healing process to the patients become more optimal.

In this time, treating wound care in Primary Health Center (PHC) Simpang IV Sipinjambi City still used conventional method by using normal saline solution. The wound healing process with this conventional method showed slowing of wound healing, caused by pain and anxiety when change wound dressing and necrotomy. Other study conducted by Nurachmah, Kristianto, andGayatri (2011) showed that comfort aspect to the patients with chronic injury in terms of transforming growth factor $\beta 1$ and cortisol levels were found the data that replacement of conventional dressing could trigger stress tissue and also pain felt by the patients which had psychological impact that causes changes in cortisol levels that play a role in the wound healing process.

Nowadays, modern dressing or modern wound care were become usually to used in Indonesia and has been recognized as an independent nurse intervention. There were several independent wound care practices that legally recognized and had an impact on decreasing amputation rates due to diabetic ulcers. Many wound care products were offer shorter wound healing. Modern wound care was option for diabetic ulcers in this time.

Modern wound care were focused to proper dressings and unrecommended to used only one dressing, various dressings could be used depend on the characteristics of the ulcer such as ulcer size, depth and exudate that found on the ulcer.Miranda andSrivasan (2016) explained that modern wound care had the characteristic of restoring and maintaining of wound moisture which could accelerate wound healing process. According to Rolstad andOvington (2007) said dressings that were used in the treatment of diabetic ulcers at this time had grown up and provide substantial contribution to the process of ulcer healing such as alginate dressing, foam dressing, collagen dressing, gauze, hydrocolloid dressing, hydrogel dressing, etc.

The study conducted byNontji (2015) about comparison between modern wound care and conventional wound care from the levels of Interlukin 1 and Interlukin 6 where the results showed that there were an acceleration of the wound healing process in modern wound care. Strengthened by research Handayani (2016) with a metaanalysis study of diabetic ulcer treatment using modern dressings showed the results that wound care using modern dressings could accelerate the process of diabetic ulcer healing. In addition, systemic study and meta-analysis which conducted by Pott et al (2014) explained that used modern dressing in various types of dressing could impact for improve wound healing.

The acceleration of healing in diabetic ulcer patients were not separated from using of modern dressing, the application run well due to nurses hadbeen equipped with knowledge and skills with drill method as learning method. During the research, nurses were required to continous nursing care to the patients to get real practical experience, so that the results obtained were expected. The ultimate target were improved competence of nursing in terms of cognitive, affective, and psychomotor aspects in modern wound care characterized by change in wound scale of diabetic ulcer patients, there were found acceleration of wound healing.

\section{CONCLUSION}


The competence of nurses in cognitive and affective aspects after giving drill method showed significantly improvement, that importance to keep using drill method to improved the competencies. For psychomotor aspect showed the same result in before and after giving drill method, that need to be maintained.Drill method as learning method that is effective to improve competency in cognitive, affective, and psychomotor aspects. For the future, this method can be expected to apply in learning process to improve competence of nursing students. That expected the learning outcomes can be match by using that method.

\section{REFERENCES}

Agustina, H. R. (2009). Perawatan Luka Modern.http://www.unpad.ac.id.Diakses 20 April 2018.

Brekke, M., Hogstad, P.H. (2010) New teaching methods - Using computer technology in physics, mathematics and computer science,ll International Journal of Digital Society (IJDS), 1(1): 18-24, 2010.

Delazer, A. Ischebeck, F. Domahs, L. Zamarian, F. Koppelstaetter, C. M. Siedentopf, L. Kaufmann, T. Benke, S. Felber, (2009)-Learning by strategies and learning by drill- evidence from an fMRI study,\| NeuroImage, 25(2005), 838-849

Diah, M. \&Rasyidah AZ. (2017) Hubungan antara Prinsip dan Jenis Balutan dengan Penerapan Tehnik Moist Wound Healing.Jurnal Endurance Kopertis Wilayah X Padang: Vol. 2, No.2.

Edi, M., Nurrahmawati \& Ajma'in. (2013). Manajemen Perawatan Luka Modern di Rumah Sakit Umum Cut Nyak Dhien Langsa. Jurnal INJEC Vol.I, No.1.

Eizenberg, M.M (2011) Implementation of evidence-based nursing practice: nurses' personal and professional factors? Journal Advance Nursing 67(1):33-42

Fransiska R., Jurianto (2016) The Use of Drilling Technique in Teaching English Vocabulary to the Seventh Grade Students of SMP Negeri 2 Tanggulangin, 5(2); 125-131
Haswita\&Lina, A..(2014). Implementasi Metode Drilland Practice Kompetensi Anatomi Fisiologi Sistem Kardiovaskuler terhadap Peningkatan Prestasi Belajar Mahasiswa Semester I Prodi DIII Keperawatan Akademi Kesehatan Rustida. Jurnal Ilmiah Kesehatan Rustida, Vol. I, No.1.

Hinno, S., Partanen, P. \&VehviläinenJulkunen, K. 2012.The professional nursing practice environment and nursereported job outcomes in two European countries: a survey of nurses in Finland and the Netherlands. Scandinavian journal of caring sciences March 2012 26 (1), 133-43.

Hamdani.(2011). Strategi belajar mengajar. Bandung: PustakaSetia

Handayani, L.T. (2016) Studi Meta Analisis Perawatan Luka Kaki Diabetes Dengan Modern Dressing, The Indonesian Journal Of Health Science 6(2); 149159

IDF.(2015). IDF Diabetes Atlas Sixth Edition Update, International Diabetes Federation

2014.http://www.idf.org/worlddiabetesd ay/toolkit/gp/fact-figures. Diakses 20 April 2018

Khetaguri, T., \& Albay, M. (2016) The Use of Drills in the Development of Speaking Skills, International Journal of Social Sciences \& Educational Studie, $3(1) ; 54-58$

Miranda, O.J., Srinivasan, G. (2016) Advanced trends in treatment of wounds, Current Science, 111( 4): 641647

Meretoja, R. \& Koponen, L. 2012. A systematic model to compare nurses' optimal and actual competencies in the clinical setting. Journal of advanced nursing Feb 2012, 68 (2), 414-22

Muslih, M (2009) KTSP: Pembelajaran Berbasis Kompetensi dan Kontekstual. Jakarta: Bumi Aksara.

Nieminen, A., Mannevaara, B. \& Fagerström, L. 2011. Advanced practice nurses' scope of practice: a qualitative study of advanced clinical competencies. Scandinavian journal of caring sciences Dec 201125 (4), 661-70

Nontji, W., Hariati, S., Arafat, R. (2015) Teknik Perawatan Luka Modern Dan 
Konvensional Terhadap Kadar Interleukin 1 Dan Interleukin 6 Pada Pasien Luka Diabetik, Jurnal Ners 10(1); 133-137

Nurachman, E., Kristianto, H., dan Gayatri, D. (2011). Aspek kenyamanan pasien luka kronik ditinjau Dari transforming growth factor $\beta 1$ dan kadar kortisol. Makara Kesehatan 15 (2): 73-80

Pott, F.S., Meier, M.J., Giseli, J., Stocco, J.D., Crozeta, K., Ribas, J.D (2014) The effectiveness of hydrocolloid dressings versus other dressings in the healing of pressure ulcers in adults and older adults: a systematic review and meta-analysis, Rev. Latino-Am. Enfermagem, 22(3):511-20

PDPERSI.(2013). Pusat Data dan Informasi.www.pdpersi.co.id

Rika, S. (2017).Pengaruh Pembelajaran Interaktif dengan Strategi Drill terhadap Kemampuan Pemahaman Konsep Matematika Mahasiswa. $J P P M$, Vol. 10, No.2

Rolstad, B.S., Ovington, L.G. (2007). Principle of wound management dalam Bryant, R., A., Nix, D., P. Acute \& chronic wound: current management concept 3th (ed.). St. Louis Missouri: Mosby Elsevier.

Sudira, I.N, Anggan, S. \&Marhaeni, A.A.I.N.

(2013).Pengaruh Metode Pembelajaran Drill terhadap Prestasi Belajar Seni Tari Ditinjau dari Kreativitas pada Siswa Kelas X SMK Negeri 3 Sukawati. $e$ Journal Program Pascasarjana Universitas Pendidikan Ganesha.Vol.4.

Suyanto\& Ahmad A.I. (2017). Modern Wound Irrigation Device (MWID) Menurunkan Jumlah Bakteri pada
Pasien dengan Ulkus Dia betikum .Jurnal INJEC, Vol.2, No.1

Susilowati, E., SigitSantoso S., Hamidi, N. (2013) Pengunaan Metode Pembelajaran Drill Sebagai Upaya Meningkatkan Prestasi Belajar Akuntansi, Jupe UNS, 1(3); 1-10

Swanto S., Din W.A. (2014) Employing Drilling Technique in Teaching English Writing Skills to a Group of Rural Malaysian Students, Developing Country Studies, 4(14); 73-82

Sagala.(2013). Konsep dan makna pembelajaran. Bandung: Alfabeta.

Usman, B (2002) Metodologi Pembelajaran Agama Islam (Jakarta: CiputatPers, 2002)

Whitman, B., \& Backes, A. (2014). The importance of role direction in simulation. Clinical Simulation in Nursing, $\quad 10(6), \quad$ e285-e289. doi:10.1016/j.ecns.2014.02.008Role

Walton, J., Chute, E., \& Ball, L. (2011). Negotiating the role of the professional nurse: The pedagogy of simulation: A grounded theory study. Journal of Professional Nursing 27(5), 299-310. doi:10.1016/j.profnurs.2011.04.005

Wenno, I.H., Wattimena, P., Maspaitela, L. (2016) Comparative Study between Drill Skill and Concept Attainment Model towards Physics Learning Achievement, International Journal of Evaluation and Research in Education (IJERE) ,5(.3): 211-215

Zapko, K.A., Ferranto,M.L., Brady, C., Corbisello, A., Hill, D., Mullen, R., DeFiore Golden, P., and Martin, L. (2015) Interdisciplinary Disaster Drill Simulation: Laying the Groundwork for Further Research, Nursing Education Perspectives. 36(6) 299-3 